\title{
Factors Affecting to Turnover Intention of Non- Managerial Employees in Apparel Industry: A Sri Lankan Experience
}

\author{
U.R.D.S.Rajapaksha ${ }^{1}$, U.W.M.R. Sampath Kappagoda ${ }^{2}$ \\ ${ }^{I}$ Research Student, Faculty of Management Studies, Rajarrata University of Si Lanka, Mihintale \\ ${ }^{2}$ Senior Lecturer, Faculty of Management Studies, Rajarrata University of Si Lanka, Mihintale
}

${ }^{*}$ Corresponding Author: U.W.M.R. Sampath Kappagoda, Senior Lecturer, Faculty of Management Studies, Rajarrata University of Si Lanka, Mihintale.

\begin{abstract}
The purpose of this study was to investigate the factors affecting to the turnover intention of nonmanagerial employees in apparel industry in Sri Lanka. For the purpose of the study, job satisfaction and organizational commitment were considered as the independent variables and the turnover intention was considered as the dependent variable. The sample was 100 randomly selected non managerial employees in the garments in Polonnaruwa district in Sri Lanka. A questionnaire was distributed among them to collect the data. The hypotheses were tested using correlation and regression analysis. The results explained that job satisfaction and organizational commitment of non-managerial employees were significantly and negatively correlated with their turnover intention. This study recommended managers to improve job satisfaction and organizational commitment of non-managerial employees to reduce their turnover intension.
\end{abstract}

Keywords: Job Satisfaction, Organizational Commitment, Turnover Intension

\section{INTRODUCTION}

The Sri Lankan apparel industry has demonstrated the tremendous growth over the past four decades and has today become the country's second largest foreign exchange earner. According to information, earning from exports of textile and apparel is accounted for $43 \%$ of total exports earnings of the country. According to Abeysinghe (2014), apparel industry accounts for nearly $70 \%$ industrial exports from Sri Lanka. The Sri Lankan government expects to position apparel industry among the top 10 high-quality manufacturers in the world and achieve US\$ 8.5 billion exports by 2020 .

However, the world market share of apparel industry it originally had in the 1980s, its competitiveness and the contribution to Sri Lanka's export sector are decreasing. The overall contribution to the economy and employment is also declining. The sector has been experiencing a severe labour shortage. It is estimated that currently 15,000 vacancies are to be filled in the industry. According to Dheerasinghe (2009) high labor turnover is one of the main challenges facing the Sri Lankan apparel industry and also it is one of the major problems that the Sri Lankan export apparel industry is facing today when they try to meet their targets (Thushari, 2008).

Turnover intention is considered by various researchers as a conscious psychological willingness to quit the work place (Griffeth et al., 2000; Ohana and Meyer, 2010; Alniacik et al., 2011; Panatik et al., 2012). According to Tett \& Meyer (1993) Turnover intention has been described as the last in a sequence of withdrawal cognitions, a set of cognitions including thinking of quitting and the intent to search for alternative employment. The turnover intension is the main source of employee turnover. The cost of turnover to organizations can be high. Given its service-intensive nature, and its relatively high labor costs in overall costs, turnover is an important issue for the apparel industry. Alkandari \& Hammad (2009) contended that the retention of human resources has been shown to be momentous to the development and the accomplishment of the organization's goals and objectives.

According to the existing information in the apparel industry, the turnover intention of employees is higher than the expected level and has become a major threat to the existence of the industry. Based on the empirical evidence, different factors can influence the turnover intention of the employees of any company, and these can stem from both the employers and the employees. If the companies know 
the most influencing factors that affect on the turnover intension of the employees, they can retain their valuable employees within the sector and reduce their expenditure. Therefore, it is very important to investigate the influencing factors on turnover intension. Among various antecedents, job satisfaction and organizational commitment of the employees are the most influencing factors on turnover intention. Therefore, the main purpose of this research is to investigate the factors affecting to turnover intention of non-managerial employees in the apparel industry in Sri Lanka. The researcher expected to achieve following objectives to address the research questions of the study.

- To examine the effect of job satisfaction on employee turnover intention

- To investigate the effect of organizational commitment on employee turnover intention

- To examine the combined effect of job satisfaction and organizational commitment on employee turnover intention.

\section{LITERATURE REVIEW}

\subsection{Turnover Intention}

Intention to turnover is defined as one's behavioral attitude to withdraw from the organization whereas turnover is considered to be the actual separation from the organization. Tett and Meyer (1993) defined turnover intention as "the last in a sequence of withdrawal cognitions, a set to which thinking of quitting and intent to search for alternative employment also belongs". Employee turnover is a critical issue for organizations because of its associated costs and negative consequences, like losing productivity, decreasing organizations profits, potential loss of valuable knowledge, skills and also intellectual capita (Atef, El Leithy and Al-Kalyoubi, 2017).

Lacity, Lyer and Rudramuniyaiah (2008) defined turnover intention as "the extent to which an employee plans to leave the organization", while other researchers described it as the conscious and deliberate willfulness to leave an organization (Mobley, 1982; Tett \& Meyer, 1993). Inversely, Vandenberg and Nelson (1999) expressed employees' intention to quit as an individual's estimated probability that they are permanently leaving their organization at some point in the near future. Intention to remain mirrors an individual's level of commitment to his organization and their willingness to remain employed (Hewitt, 2004).

There are lots of factors that affect to turnover intention. Among various antecedents of turnover intention, job satisfaction and organizational commitment appear to be good predictor of turnover intention (Chen, 2006; Alniacik et al., 2011; Atef, El Leithy and Al-Kalyoubi, 2017; Tnay, Othman, Siong \& Lim ,2013; Islam, Rafiqul and Tanzia, 2016).

\subsection{Job Satisfaction, Organizational Commitment and Turnover Intention}

Robbins (2005) defined job satisfaction as a subjective measure of worker attitudes, that is, an individual's general attitudes to his or her job. An employee with high job satisfaction holds positive attitudes towards their job and an employee with high job dissatisfaction holds negative attitudes towards his or her job. Ivancevich and Mattson (2005) explained job satisfaction as an attitude that individuals have towards their jobs which stems from their perception of their jobs and the degree to which there is a good fit between the individual and the organization. Robbins \& Judge (2007) defined job satisfaction as a positive feeling about one's job resulting from an evaluation of its characteristics.

As noted by Lambert et al., (2001), scholars speculate that employee turnover can be predicted using comprehensive measures of job satisfaction; otherwise stated, high job satisfaction is associated with low employee turnover. When the employees are not satisfied with their jobs and organizations do have not trust in their employees the employee's intention towards turn over will be greater, they will leave the organization and the duration of their job will be smaller (Jeffrey, 2007). Issa, Ahmad and Gelaidan (2013) found that there was a significant negative relationship between job satisfaction and turnover intention. The result highlighted that pay satisfaction was the dominant dimension of job satisfaction in term of effecting turnover intention. Rahman \& Iqbal (2013) reveal that there is a strong relationship between job satisfaction and employees' turnover intention at private commercial banks in Bangladesh. According to Susskind et al, (2000) job satisfaction has a significantly negative association with turnover intention on consistent basis. According to Blau (1987) researchers have 
proved that job satisfaction has direct influence over the turnover intention. Job dissatisfaction has been stated to be one of the most major and consistent predictor of turnover intention of healthcare workers (Steinmetz, Vries \& Tijdens, 2014; David, Chakraborty, Mahapatra and Steinhardt, 2010; Ojakaa, Olango and Jarvis, 2014). Mowday (1984) stress that Job satisfaction of healthcare workers arises from relations between experience and work environment and is greatly essential for healthcare workers' retention. Existing studies confirmed a relationship between the low job satisfaction, the low motivation, and the turnover intention (Ojedokun, 2008). Hence the following hypothesis is suggested:

H1: There is a negative relationship between job satisfaction and turnover intention of employees in Apparel sector in Sri Lanka

Organizational Commitment is an "emotional attachment to an organization; a goals and values which results in willingness to exert optimal effort to achieve the organizations goals". Commitment is a multi-faceted concept developed a three dimensional model encompassing affective, normative and continuance commitment (Meyer \& Allen, 1997). Employee's commitment to the organization has effects on the employees themselves, on the organization and on the society. The researchers have found negative relationship between organizational commitment and turnover intention.

Rasheed and Jehanzeb (2013) has conducted a research on Organizational Commitment and Turnover Intentions using a sample of 350 employees and found a strong negative relationship between organizational commitment and turnover intention. Sjorberg \& Sverke (2000) also found negative relationship between organizational commitment and turnover intention. A similar result was found by lots of researchers (Ramendran \& Kumar, 2012; Hussain,Asif \& Salleh,2012; Sinem \& Baris , 2011; Salleh, Nair, \& Harun, 2012). Hence the following hypothesis is suggested:

$\mathrm{H} 2$ : There is a negative relationship between organizational commitment and turnover intention of employees in Apparel sector in Sri Lanka

\section{RESEARCH METHODOLOGY 3.1 The Research Design}

In this study, the researcher tries to examine the relationship between job satisfaction, organizational commitment and turnover intention. Therefore, the purpose of this study is hypothesis testing that seeks to explore the relationships among variables. The current study employed a correlational study in order to explore the relationship between job satisfaction, organizational commitment of the employees (independent variables) and their turnover intention (dependent variable). This field study is conducted in natural environment in apparel sector under minimal interference with non-contrived settings. This study is a cross sectional study. For this purpose, data will have to be collected from each non managerial employee in apparel industry in Sri Lanka. Therefore, the unit of analysis of this research is "individual".

\subsection{Population and Sample}

The sample of this study was drawn from a population comprised of all the non-managerial employees of apparel sector in Pollonnaruwa District in Sri Lanka. The study was conducted using 165 non managerial employees from Pollonnaruwa district. The sample was randomly selected. 53 employees were male and 112 were female.

\subsection{Measures}

Three variables in the research: Job satisfaction, organizational commitment and turnover intention were measured through standard questionnaires with five -point Likert scales, ranging from 1 (strongly disagree) to 5(strongly agree). The level of job satisfaction, organizational commitment and turnover intention of the employees were evaluated by themselves. Turnover intention was measured using a standard questionnaire consisting 03 statements. Job satisfaction was measured using 25 statements and organizational commitment was measured by an instrument consisting 11 statements.

\subsection{Validity and Reliability}

The content validity of these instruments was secured by including an adequate number of questions for each dimension of the variables. The results of Cronbach Coefficient Alpha (table 01) which 
Factors Affecting to Turnover Intention of Non- Managerial Employees in Apparel Industry: A Sri Lankan Experience

suggested each item is correlated with other item across the entire sample and the internal consistency reliability is satisfactory.

Table 1: Cronbach Coefficient Alpha Value for variables

\begin{tabular}{|l|c|c|}
\hline \multicolumn{1}{|c|}{ Variables } & Cronbach Coefficient Alpha & Number of Items \\
\hline Job satisfaction & 0.826 & 25 \\
\hline Organizational Commitment & 0.850 & 11 \\
\hline Turnover intention & 0.843 & 03 \\
\hline
\end{tabular}

\subsection{Data Analysis}

The data analysis included univariate, bivariate and multivariate analyses. SPSS data analysis package of 17 th version was used to analyze the data.

Table 2: Descriptive statistics for variables

\begin{tabular}{|l|l|l|}
\hline \multicolumn{1}{|c|}{ Variable } & \multicolumn{1}{c|}{ Mean } & \multicolumn{1}{c|}{ Std. Deviation } \\
\hline Job Satisfaction & 2.7107 & 0.35602 \\
\hline Organizational Commitment & 2.7167 & 0.64631 \\
\hline Turnover intention & 3.3433 & 0.3654 \\
\hline
\end{tabular}

The data presented in Table 2 shows that the level of job satisfaction and organizational commitment of the employees is lower in the apparel sector in Sri Lanka. In turn, turnover intention of the non managerial employees is comparatively high in selected garment factories.

Table 3: Correlations between variables

\begin{tabular}{|l|l|}
\hline & \multicolumn{1}{|c|}{ Turnover intention } \\
\hline Job Satisfaction & -0.65 \\
\hline Organizational commitment & -0.72 \\
\hline
\end{tabular}

** Correlation is significant at 0.01 level (1-tailed)

Table 4: The results of regression analysis

\begin{tabular}{|c|c|c|c|c|c|}
\hline$R^{2}=.478$ & $=85.60$ & & & & \\
\hline \multirow[t]{2}{*}{ Model } & \multicolumn{2}{|c|}{$\begin{array}{l}\text { Unstandardized } \\
\text { Coefficients }\end{array}$} & \multirow{2}{*}{\begin{tabular}{|l|}
$\begin{array}{l}\text { Standardized } \\
\text { Coefficients }\end{array}$ \\
Beta
\end{tabular}} & \multirow[t]{2}{*}{$\mathrm{t}$} & \multirow[t]{2}{*}{ Sig. } \\
\hline & $\mathrm{B}$ & Std. Error & & & \\
\hline (Constant) & 4.189 & 1.088 & & 3.848 & .00 \\
\hline Job Satisfaction & -.264 & .361 & -.074 & -.732 & .000 \\
\hline Organizational Commitment & -.048 & .199 & -.024 & -.239 & .004 \\
\hline
\end{tabular}

The results of the correlations coefficient between job satisfaction, organizational commitment and turnover intention of employees are presented in Table 03. According to the results, the correlation between job satisfaction and turnover intention $(r=-0.65, \mathrm{p}<0.01)$ was significant and negative. The correlation between organizational commitment and turnover intention $(\mathrm{r}=-0.72, \mathrm{p}<0.01)$ was also significant and negative.

According to the result of the regression analysis is reported in table 04. There are negative relationships between job satisfaction and turnover intention $(\beta=-0.264, p=0.00)$ and organizational commitment and turnover intention $(\beta=-0.048, p=0.00)$ of the employees in apparel sector in Sri Lanka. Thus, the both hypotheses are supported by the data. And also, job satisfaction and organizational commitment explain $47.8 \%$ of the variance in turnover intention.

\section{DisCUSSION AND CONCLUSION}

The main objective of this study was to examine the relationships between job satisfaction, organizational commitment and turnover intention. The results of correlation coefficient and regression analysis indicated that job satisfaction and organizational commitment of employees has significantly and negatively correlated with turnover intention. $\mathrm{R}^{2}$ value is 0.478 which means $47.8 \%$ of the variation can significantly be explained by the independent variables (job satisfaction and organizational commitment). 
The result of this study was generally consistent with previous studies. Ali (2007); Salleh, Nahir and Harun (2012) found negative relationship between job satisfaction and turnover intention. Hussain and Asif (2006); Rasheed, (2013) found negative relationship between organizational commitment and turnover intention. Chen (2006); Sinem and Baris (2011) found significant negative relationship between job satisfaction, organizational commitment and turnover intention.

Overall, the findings have highlighted the importance of job satisfaction and organizational commitment in influencing turnover intention of the employees in the apparel sector. High labor turnover is one of the main challenges facing the Sri Lankan apparel industry and also it is one of the major problems that the Sri Lankan export apparel industry is facing today when they try to meet their targets. Job satisfaction and organizational commitment both together explained around 50\% variation in turnover intention. That means job satisfaction and organizational commitment is two main factors that affect turnover intention of the employees in apparel industry in Sri Lanka. These findings are useful in highlighting the need for the company to develop appropriate strategies and human resource practices in order to reduce its high employee turnover in the future.

\section{REFERENCES}

[1] Abeysinghe, B. (2014). The time has come for Sri Lanka to look beyond apparel exports. Daily FT. Retrieved from http://www.ft.lk /2016/01/20/the-time-has-come-for-Sri-Lanka-to look beyond apparelexports

[2] Alkandari, Q., \& Hammad, A.A. (2009). Employees retention in private sector: an exploratory study in the state of Kuwait. Unpublished MBA dissertation, Open university, Malaysia.

[3] Alniacik, U., Cigerim, E., Akein, K., \& Bayram, O., (2011). Independent and joint effects of perceived corporate reputation, affective commitment and job satisfaction on turnover intentions, Procedia - Social and Behavioral Sciences, 24, 1177-1189.

[4] Atef, G., El Leithy, W., \& Al- Kalyoubi, M. (2017). Factors affecting employees' turnover intention, International Business Management, 11, 118-130.

[5] Blau, G.J. (1987). Locus of control as a potential moderator of the turnover process, Journal of Occupational Psychology, 60(1)1, 21-29.

[6] Chen, C. F., (2006), “Job satisfaction, organizational commitment, and flight attendants' turnover intentions: A note", Journal of Air Transport Management, Vol. 12, pp. 274-276.

[7] David, H.P., Chakraborty, S., Mahapatra, P, Steinhardt L. (2010). Job satisfaction and motivation of health workers in public and private sectors: cross-sectional analysis from two Indian states. Human Resource Health. 8, 27.

[8] Dheerasinghe, R. (2009). Garment Industry in Sri Lanka Challenges, Prospects and Strategies. Staff studies, 33(1\&2). 33-72.Doi: 10.4038/ss.v33i1.1246

[9] Griffeth, R.W., Hom, P.W., Gaetner, S., (2000). A meta-analysis of antecedents and correlates of employee turnover: update, moderator tests, and research implication for the next millennium, Journal of Management, 26, 463-488.

[10] Hewitt Associates. (2004, February). Strategies for cost management of the HR function. Timely Topics. Retrieved from http://hrledger.com/library/HR_Costs_Hewitt_2004.pdf

[11] Hussain, T., \& Asif, S. (2012). Is Employees' Turnover Intention Driven By Organizational Commitment And Perceived Organizational Support? Journal of Quality and Technology Management, 1-10.

[12] Islam, Md. Rafiqul and Rahman, Tanzia. (2016). Relationship between Job Satisfaction, Organizational Commitment and Turnover Intention among Bank Employees: A Study on Selected Banks of Bangladesh, Scholar Journal of Business and Social Science, 2(1),7-18.

[13] Issa, D. A., Ahmad, F., \& Gelaidan, H. M. (2013). Job Satisfaction and Turnover Intention Based on Sales Person Standpoint. Middle-East Journal of Scientific Research, 525-531.

[14] Ivancevich, J. M and Matteson, M T (2005). "The Measurement of Experienced Evidence." Journal of Occupational Behaviour, 10(2), 99-113.

[15] Jeffrey Pfeffer (2007). Human Resources from an Organizational Behavior Perspective: Some Paradoxes Explained. The Journal of Economic Perspectives, 21(4), 115134.

[16] Lacity, M. C., Lyer, V. V., \& Rudramuniyaiah, P. S. (2008). Turnover intentions of Indian IS professionals. Information Systems Frontiers on Outsourcing, 10, 225- 241. 
[17] Lambert, E. G., Hogan, N.L., \& Barton, S. M. (2001). The impact of job satisfaction on turnover intent: a test of a structural measurement model using a national sample of workers. The Social Science Journal, 38(2), 233-250. doi:10.1016/S0362-3319(01)00110-0

[18] Meyer, J., \& Allen, N. .. (1997). Commitment in the workplace. Thousand Oaks

[19] Mobley, W. H. (1982). Employee turnover: Causes, consequences, and control. Reading, MA: AddisonWesley.

[20] Mowday, R. T. (1984). Strategies for adapting to high rate of employee turnover. Human Resource Management. 23(4), 365-380.

[21] Ohana, M., and Meyer, M. (2010), Should I stay or should I go now? Investigating the intention to quit of the permanent staff in social enterprises, European Management Journal, 28, 441-454.

[22] Ojakaa D, Olango S, Jarvis J.(2014). Factors affecting motivation and retention of primary health care workers in three disparate regions in Kenya. Human Resources Health.12, 33.

[23] Ojedokun, A.,O. (2008). Perceived job insecurity, job satisfaction and intention to quit. African Journal of Psychological Study and Social Issue, 11(2),204-220.

[24] Panatik, S. A. B., Rajab, A., Shaari, R., Saat, M. M., Wahab, S. A., \& Noordin, N. F. M., (2012). Psychosocial Work Condition and Work Attitudes: Testing of the Effort-Reward Imbalance Model in Malaysia, Procedia - Social and Behavioral Sciences, 40, 591-595.

[25] Rahman, M., \& Iqbal, F. (2013). A Comprehensive Relationship between Job Satisfaction and Turnover Intention of Private Commercial Bank Employees' in Bangladesh. International Journal of Science and Research, 2 (6), 17-23.

[26] Ramendran, C., \& Kumar, R. (2012). A Study on Turnover Intention in Fast Food Industry. International Journal of Academic Research in Business and Social Sciences.

[27] Rasheed, A., Jehanzeb, K., \& Rasheed, M. F. (2013). An investigation of the antecedents of organizational citizenship behaviour: Case of Saudi Arabia. International Journal of Psychological Studies, 5(1), 128.

[28] Robbins. (2005). Essentials of organisational behaviour. New Jersey: Prentice Hall.

[29] Robbins, S.P. and Judge, T.A. (2007). Organizational Behaviour. (12th ed.) New Jersey: Prentice-Hall.

[30] Salleh, R., Nair, M. S., \& Harun , H. (2012). Job Satisfaction, Organizational Commitment, and Turnover Intention: A Case Study on Employees of a Retail Company in Malaysia. International Journal of Social, Education, Economics and Management Engineering, 702-709.

[31] Sinem, A., \& Baris , A. (2011). An Empirical Study of the Relationship Among Job Satisfaction,Organizational Commitment and Turnover Intention. International Review of Management and Marketing, 51-52

[32] Sjöberg, A., \& Sverke, M. (2000). The interactive effect of job involvement and organizational commitment on job turnover revisited: A note on the mediating role of turnover intention. Scandinavian Journal of Psychology, 41, 247-252.

[33] Steinmetz, S., de Vries, D.H,, Tijdens, K.G. (2014). Should I stay or should I go? The impact of working time and wages on retention in the health workforce, Human Resources Health, 12-23.

[34] Susskind, A.M., Borchgrevink, C.P., Kacmar, K.M. and Brymer, R.A. (2000). Customer service Employeese behavioral intentions and attitudes: an examination of construct validity and a path model, International Journal of Hospitality Management, 19(1), 53-77.

[35] Tett, R. \& Meyer, J.,(1993). Job satisfaction, organizational commitment, turnover intention and turnover: path analyses based on meta-analytic findings, Personnel Psychology, 46, 259-293.

[36] Thushari, W. K. D., (2008). An empirical investigation into Absenteeism and labor turnover in the Sri Lankan export apparel manufacturing industry, unpublished dissertation.

[37] Tnay, E., Ekhsan, A., Othman, A., Siong, H. C., Lim, S., Lim, O. (2013). The Influences of Job Satisfaction and Organizational Commitment on Turnover Intention, Procedia - Social and Behavioral Sciences, 97(6), 201-208.

[38] Vandenberg R. J., \& Nelson J. B. (1999) Disaggregating the motives underlying turnover intentions: When do intentions predict turnover behaviour? Human Relations, 52(10), 1313-1336. 


\section{AUTHOR'S BIOGRAPHY}

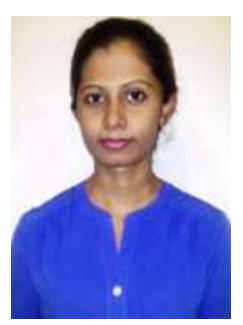

U.R.D.S. Rajapaksha, is a graduate of Rajarata University of Sri Lanka. She obtained her degree in BSc. (Management) special from the same university and now she is reading her Master degree in Business Management. She works as an Executive officer at the private company in Sri Lanka.

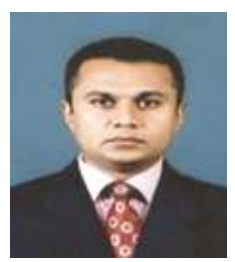

U.W.M.R. Sampath Kappagoda, is a Senior Lecturer at Rajarata University of Sri Lanka. He graduated from University of Sri Jayewardenepura, Sri Lanka. He received his master degree from University of Kelaniya and obtained his PHD in Positive Psychology in 2015 from Management and Science University, Malaysia. He has authored over 25 research articles and worked as a reviewer and editor of national and international research journals. The current research interests of Dr. Kappagoda include Emotional Intelligence, Psychological Capital, Job Performance, Work Attitudes, Work Life Balance and Mindfulness. In addition to research, he teaches Organizational Behaviour and Positive Psychology to graduate and postgraduate students. He also works as a counselor in the Rajarata University of Sri Lanka.

Citation: U.R.D.S. Rajapaksha \& U.W.M.R. Sampath Kappagoda. " Factors Affecting to Turnover Intention of Non- Managerial Employees in Apparel Industry: A Sri Lankan Experience" International Journal of Managerial Studies and Research (IJMSR), vol 5, no. 11, 2017, pp. 76-82. doi: http://dx.doi.org/10.20431/ 2349-0349.0511008.

Copyright: () 2017 Authors. This is an open-access article distributed under the terms of the Creative Commons Attribution License, which permits unrestricted use, distribution, and reproduction in any medium, 